\title{
GENDER PARITY AND WOMEN EMPOWERMENT IN EUROPE: EFFORTS OF EUROPEAN UNION
}

\author{
Dr. Rani Erum \\ Department of Political Science \\ Federal Urdu University Karachi, Pakistan \\ http://www.rani.irum@fuuast.edu.pk \\ https://orcid.org/0000-0002-3845-8899 \\ Prof. Dr Sayeda Daud \\ Dean of Social Sciences \\ Greenwich University, Karachi \\ sayedadaud@gmail.com \\ https://orcid.org/0000-0002-6867-8489
}

\begin{abstract}
This paper analyses the character of the European Union in the development of gender equivalence and the empowerment of women. It includes the place of gender in EU development policy (EUDP), and core reasons that placing it in such a momentous policy of the most important continent of the world. The study covers legal situation of gender equality and mainstreaming in EU policies but it has more focus on EEC and national policies of member nations for two basic reasons. Foremost, the transformation in the domain of gender uniformity based in core strategies of EU countries to effect only than it has acquire legal and executing powers. Secondly, the Sustainable Development Goals (SDGs), which are part of Agenda 2030, are general and hence implement on all EU nations.
\end{abstract}

KEYWORDS: Women empowerment, Gender Equality, Mainstreaming, Hard laws, Soft Laws, Universal Goals,

\section{INTRODUCTION}

Gender equality is the basic human right and its provision is the essential responsibility of every state. Women and girls can play a vital part in social and financial growth of the 


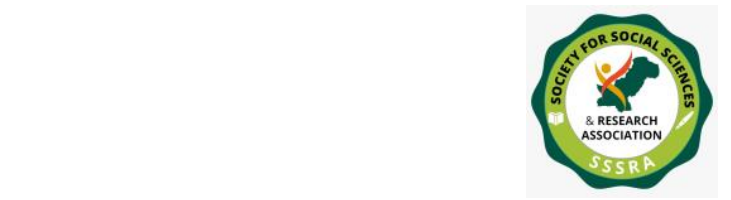

Pak. Journal of Int'L Affairs, Vol 4, Issue 2 (2021)

Gender Parity and Women Empowerment ...

society and it is impossible for any nation to get progress without giving equal status to their half female population. The world realizes the importance of gender uniformity in last century and since than it had become an important issue and almost all international and regional organizations showed great interest to eradicate the unequal treatment with women in all parts of the world. $21^{\text {st }}$ century not only increases the issue but also stand out the goal of women empowerment as the target for the future policies of major organizations and nations policies. Therefore it becomes an increasing interest and important principle for European Union policy-makers with its establishment. Despite the existence of many feminine organizations such as European Women's Lobby (EWL), the European Women Lawyers Association (EWLA), and Women in Development Europe (WED), in the European continent, as a collection women have never been structured around gender discrimination. Thus, at the end of $20^{\text {th }}$ century the women remain steadily differentiated and left behind with facing persistent violations of their rights.

\section{RESEARCH PROBLEM}

The core reason of the research is to study the role of EU as an economic organization in gender equality among the member states. Precisely, the essay chiefly circles round the notion of the EU initiatives and its proposition to aid in encouraging the women empowerment system. Along with the above mentioned research problem, the other aims of specific study are:

- To evaluate contextual past of the European struggle in maintaining gender equality and women empowerment.

- To study the EU's initiatives for development of women since1957.

- To highlighting the legislation by EEC for gender equality and main streaming.

- To find out future prospects of gender equality in EU nations.

\section{RESEARCH METHODOLOGY}

The research is envisioned on a qualitative methodology and established on accessible literature analysis on the research problem. In accordance to the nature of research objectives, extensive work has been made to gather factual data from different sources. Hence it is an amalgamation of primary and secondary sources. All the data has been collected from authentic sources and original documents such as the EEC treaties, books, journals, speeches, statements and official declarations and communications. Apart of literary research communication with other scholars through international seminars, conferences and workshops, has been very beneficial in mounting precision in discerning 


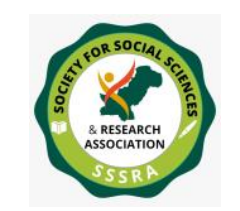

Pak. Journal of Int'L Affairs, Vol 4, Issue 2 (2021)

Gender Parity and Women Empowerment ...

about many features of the subject.

\section{SIGNIFICANCE OF THE STUDY}

The respective essay is prepared in different segments. The preliminary portion of the research, deals with the objectives and methodology of research. Whereas the next part focuses on the brief back ground of emergence of gender equality in European Union. The third one related with the EU policy toward women rights, gender equality, mainstreaming and women empowerment under the different treaties and internal legislation of EEC. A summary of outcomes, suggestions and some future prospects for the research problems would be discusses at last. It is estimated that the outcomes of the work would not only empower the intellectuals and authorities of gender politics and women rights activism but it would be also provide an in depth knowledge to the students, women rights activist and policymakers of gender studies.

\section{EUROPEAN UNION (EU)}

European Union is the most dynamic and successful regional economic organization of the World. It was the result of a pain staking process that began with the creation of the European Coal and Steel Community (ECSC) in 1950 by six nations of Europe; France, Germany, Belgium, Italy, Luxembourg and Netherlands (Pinder and Usherwood 2013: 02). The French official Monnet, was the first President of the community. All these nations saw the new group as a tactic to ensure harmony by tiding Germany within strong European foundations as a precaution after the outrageous retro of Nazi Hitler. Initially the political motives was a profound purpose for establishing a new community but that goal could not achieved without sustainable economic performance and the adequate enactment in the fiscal field given it powers thus the Community served as an economic organ with the political logic. The next development occurred in 1954 by creating European Defence Community (EDC) with this, the six founding states proceeded yet again on the route of economic incorporation although French assembly did not ratify the EDC treaty. The idea of common market was extended by the foundation of European Economic Community (EEC) in 1958. It opened up the path to cohesive economy that provided the logic of economic interdependence among the member states (Ibid, 05). The EEC and Euratom (European Atomic Energy Community) was the result of two pacts contracted in Rome in 1957 and come into force on 1 January 1958 called the treaties of Rome. Other major treaties included the ECSC Treaty which in force in 1952, the (SEA) Single European Act in 1987, MT (Maastricht Treaty) in 1993, AT (Amsterdam Treaty) in 1999, NT (Nice Treaty) in 2002, and the LT (Lisbon Treaty) in 2009 (Ibid, 35). Three more countries; Britain, Denmark and Ireland joined the EEC in January 1973 whereas 


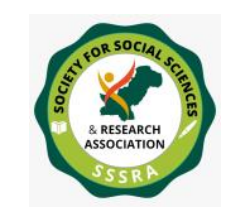

Pak. Journal of Int'L Affairs, Vol 4, Issue 2 (2021)

Gender Parity and Women Empowerment ...

Greece become the member in 1981 and two other countries Spain and Portugal joined the community in 1986. This enlargement increased the role and powers of EEC from North Sea to Mediterranean Sea.

European Union was officially established in 1993 by the Maastricht Treaty, along with two new 'pillars' for foreign policy and internal security with the European Community. The EU enlarged in 1995 with the membership of Austria, Finland, and Sweden and by 2004, the Czech Republic, Estonia, Hungary, Latvia, Lithuania, Poland, Slovakia, Slovenia, Cyprus and Malta joined the organization whereas Bulgaria and Romania joined in 2007 and with the accession of Croatia in mid-2013, the EU members reached to 28. EU developed itself in a fiscal field in all over the Europe with open market, single currency, and identical pay for men and women, equivalent labor rights, lemmatized the boundaries role for the citizens of member states. This process was very swiftly proceeding till the Britain, Denmark and Ireland raised their voices against extended territorial freedom among the member states and later in 2016 the BREXIT (Britain exit) from EU traumatized the union future goals.

\section{BACKGROUND OF GENDER EMANCIPATION IN EU}

The gender equivalence in the EU started with the statutory treaty of Rome who established the EEC in 1957. The Article 119 of the 1957 TR (Treaty of Rome) accepted similar pay for women and men for similar work. The specified article evidently exhibited the future direction of new Europe but the suggested action, such as; identical measures for men and women in work place or same remuneration for time was an initial step which was based on the goal to equal labor costs and it was not to attain gender parity. The Article 119 of Treaty of Rome essentially for the needs of the labor sooq, but never deliberated the welfares of women (Hoskyns 1996: 56). However, it was the beginning of framework of an enduring promotion of post- World War II human rights, although the discussion was not precisely intended to magnify women's rights but was generally applied for women as well as men (Shaw 2002: 213-226). The first legendary occasion took place in 1966, when more than 3,000 female staff from a Belgian weapons unit in Herstal went on strike to protest against inadequate pay. In 1965 at the "Fabrique Nationale d'Armes de Guerre" women earned 25 percent less than male staff for the similar work (Debusscher, 2015(4): 04). Soon that becomes an extensive remonstration against the unsatisfactory position of women in society. The strike was reinforced by many factories in the area and was instantly supported by feminist organizations and labor unions outside of Belgium as well. They initially used article 119 as basic demand in their movement. The strike was continued for three months and get limited attainment but the women's protest and fractional success had a significant symbolic value and 


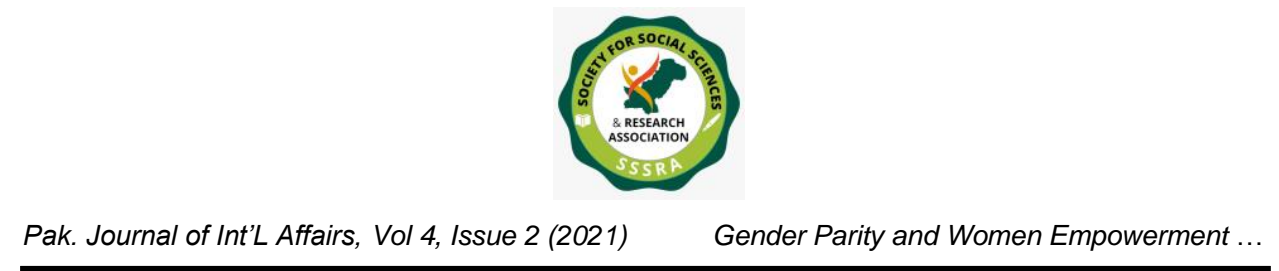

inspired many European men and women (Debusscher, 2015(4): 04). Almost after ten years women activists would come to realize its prospects and

"Switch the debate from one of economic rationality to a demand for rights" (Hoskyns 1996: 57).

That period was also observed the growth and unification of the women's movement across Europe, including more fundamental methods of feminism and social action connecting the young generation (Woodward 2012).

In the decade of 70s women's organizations and other social organizations put the gender parity on a high place on their political programs. Additionally, the United Nations was also announced 1975 as International Women's Year and had advised all its members in 1973 to take tangible arrangements to develop the place of women till 1975. Common European response was very welcoming for UN advice because all of them were facing this task equally at home. Therefore, all member countries agreed on proposed demands in their countries by European equality policy. But despite of agreeing on gender equality principle it was not easy for them to made proper legislation to legalize it because of high cost of its implementation. Later in 1980s things getting worse because of 1979 oil crisis and legal process faced impasse, states become more reluctant to agree on new policies. During that time, democrats in the European Commission progressively use lenient legal measures ( as non-binding rules and recommendations for the members and action programs) to upsurge the effect of EU parity instructions, increase community cognizance of women's concerns and encourage equivalent prospects for women and men outside the place of work (van der Vleuten 2007a).

The legal deadlock was continued till 1992 for strong gender equality legislation. Until, fresh measures were presented by the Maastricht Treaty in February 7, 1992. That treaty brought two important changes:

1. The European Parliament was become complete authority next to the Council of Ministers, which amplified the probabilities for a more reformist EU gender policy.

2. A Social Protocol was attached to the EU Treaty. (Van der Vleuten 2007a).

\section{The Social Protocol: a new decision making procedure that gave the European social partners an official role in EU policy making.}

Nonetheless Maastricht treaty created a space for a social dimension of European assimilation and a hope for women future equal economic status and empowerment. In 


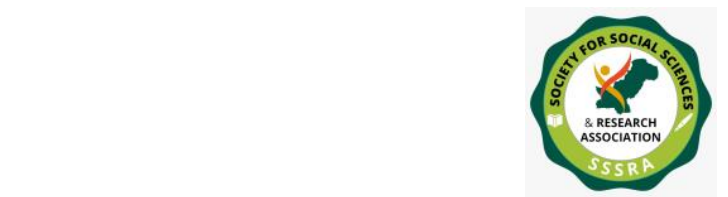

Pak. Journal of Int'L Affairs, Vol 4, Issue 2 (2021)

Gender Parity and Women Empowerment ...

1997 Amsterdam Treaty was signed which not only strengthened the role of the European Parliament further but also made parity between both genders among the EU nations. The treaty also professed its explicit objectives and activities, which embedded the principle of gender fairness in the EU Agreement. The treaties of 1992 and 1997 brought change and end the barriers of forming strong law on gender equality. The gender parity as a core strategy principle in the European Union has established as a forward step of UNO. Particularly the fourth UN World Conference in Beijing played a very substantial role to boost the speed of reforms regarding gender equality in EU nations. For example, EU provision for 'constructive discrimination' in support of women in work to counterbalance former perception, and actions to contest sexual harassment in the place of work have been very limited (European Commission 2000a). That process since then never stops, it hurdled, slowdown or some time swift and jumped but continue.

\section{PHASES OF DEVELOPMENT OF GENDER EQUIVALENCE POLICY IN EU}

The EU determinedly backings gender impartiality and enablement of women worldwide, working to the exclusion of the hurdles on the way. The vital significance of respective phenomenon in advance policies is acknowledged in several documents. The deliberate commitment for gender parity of European Union highlights the five core areas of promotion of gender equality and women's rights all over the realm. The evolution in EU gender parity policy can be defined in three phases. The first phase related to the liberal feminist belief which is;

"No individual should have fewer rights or opportunities than any other" and also believed that "legal redress to treat men and women the same" (Rees 1998, 29 and 2002, 46).

This methodology also based on article 119 of the famous TR (treaty of Rome) and the related chain of guidelines on equivalent pay and the same conduct in the place of work. EU has increased its equal treatment legislation with positive action initiatives from many years and now it reaches the fact that there is no swift way to achieve the task of equal gender treatment, similarly does not have a procedure to get an equal outcome automatically. Things getting better day by day with continues painstaking hard work and one day feminist liberals will achieve their desired aim.

The second phase related with the approach of Positive action which is traditionally a feminist culture that later shifted as a goal from equal access to equal outcomes by creating the conditions that will more likely lead to equalizing starting positions (Verloo and Lombardo 2007: 28). During the period of 80s the European mainstream feminist 


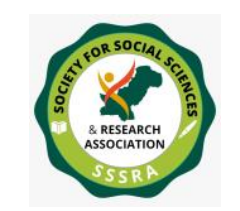

Gender Parity and Women Empowerment ...

forums active for gender equality. Their main focus was to create an environment where women can work in a peaceful and secure way and that become a system for whole society without creating a slight feeling for opposite gender as their enemy or rival. It was a difficult task in EU because the positive actions were originally introduced by nonbinding soft laws which already create legal confusion in Europe.

The third phase based on the gender mainstreaming approach. This method is related with postmodern feminism and the concept of transformation (Verloo and Lombardo 2007: 33). It was accepted by the UN at the 1995 Beijing women conference and later embraced by the EU its member and international development agencies and because of these efforts gender mainstreaming is now become "an international phenomenon" (Squires, 2007: 45). It contain study of how present structures benefited men or become a reason of unintended insight and find ways to reform these arrangements and edifices so that they bring considerable equivalence between men and women (Rees 2002). Gender mainstreaming also applies a system approach because of believing the prospects of change in discerning gender customs, organizations and relations. It is described by the European Commission as:

"the integration of a gender perspective into every stage of policy processes - design, implementation, monitoring and evaluation - with a view to promoting equality between women and men" (European Commission 2011).

The European awareness of gender mainstreaming is more technical instead of hypothetical and it emphases on the current strategy elements and procedures and to a slightly proceed on reconsidering developments or on encompassing excepted groups in policy making.

\section{THE OBJECTIVE OF GENDER PARITY IN THE NEW MILLENNIUM}

The new millennium not only shaped European Union but also designed the concept of Europeanization and women empowerment. It brought a new way to gender indiscrimination in Europe. In fact the scholars believed that gender fairness was a significant feature and one of the core ideology of the EU. A specific approach behind the perception of equivalence between men and women has been united into the identity of the EU and its foundations, engrained in agreements and main legislation and constantly visible in formal publications and communications (Macrae, 2010:155-174). The EU today conceits itself on some of the most innovative policies to promote gender equality in the world but people should understand that the EU is an organization not a conventional nation-state and its powers eventually depend on agreements signature by all member nations which mean that the European Union is little more than an inter- 


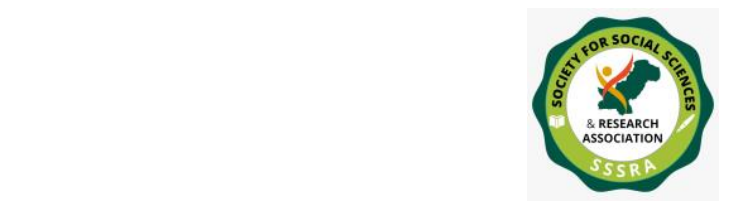

Pak. Journal of Int'L Affairs, Vol 4, Issue 2 (2021)

Gender Parity and Women Empowerment ...

governmental board, which has the role to complete the internal policies of member states more effectively than by themselves (Moravcsik, 1993: 473-526).

There are three stimulating and interconnecting features about the character of the EU in determining relations of men and women in Europe.

- Firstly, the European Union has its own gender strategies as proved by its similar opportunities guidelines and gender plans such as policies on family and violence, and trade and agriculture (Kantola, 2010: 02).

- Secondly, the communication among the institutional bodies, procedures, actors and treatises in the European Union is gendered and gendering (Ibid: 04).

- Thirdly, the EU is a multi-level organization which indicates that it work together in a very complex way and reach to legislate gender legislation and policy (Ibid: 06).

-

These three characteristics not exhibits the awareness of EU nations but also showed the advancement of tactics of EU regarding strong application of enforcement of equality from its platform.

\section{LEGISLATION BY EU FOR GENDER EQUALITY AND MAINSTEAMING}

The gender quality based legislation in Europe started with Treaty of Rome in 1957, since then gradually required legislation had been done by European commission to provide equal measures to European women. The legislation occurred in the form of hard laws and soft laws from 1970s till date. It was began with the approval of two basic directives related to the equal pay and no equal conduct in the middle of the 1970s which became the foundation in EU gender indiscriminant policy.

\section{- Lawmaking in Mid-1970s -1980s}

EEC properly started legislation related with women equal status in 1970s. Primarily EEC treaties drafted on Equal pay and later on the subjects of gender discrimination, and identical conduct in social security. This legislation first occurred in 1975 and then reformed in 2006. The treaties related with equivalent treatment of men and women in legal systems of social security formed in 1979 whereas the occupational social security schemes was include in it in 1986 and amended in 1996 and in 2006. The legislation related with equal conduct with men and women involved in an independent volume, including in agriculture shaped in 1986 and repealed and amended in 2010.

\section{- Legislation in 1990s- 2000s}

EEC started legislation related with the Family leave, equal dealing for part-time workers, and other Labour standards in which Maternity leave legalized in 1992, Parental 


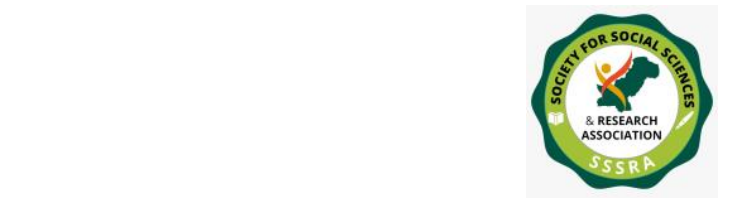

Pak. Journal of Int'L Affairs, Vol 4, Issue 2 (2021)

Gender Parity and Women Empowerment ...

Leave in 1996 which re-affirm in 2010. The Equal treatment for part-time workers legislated in 1997, Fixed-Term Work in 1999 and Working Time fixation held in 2003.

The Equal treatment for consumer rights came under the law in 2004 to 2012 in which the same conduct of men and women in the entrance to, and the supply of, goods and service legalized in 2004 and gender quotas for corporate boards 2012.

All the hard laws are related with basic equal rights which illustrated in Universal Declaration of Human Rights (UDHR) such as equal pay, sex discrimination, equal action of men and women in service, similar labor rights, financial rights, parental and maternal leaves, working time, fixed term etc. All mentioned issues needed strong legislation thus hard laws provided endorsed strength to the future task of women empowerment.

Despite the hard laws EU Commission also work on those areas where legislation needed in the shape of soft policies, guidelines and policy sharing. The respective table suggested that two developments of soft laws prompted a developing character from the mid-1990s ahead as an instrument for promoting gender equality.

The emphasis on gender parity and gender mainstreaming exceeded in late 1990s and it showed to be on the rising place in the EES, and steadily relegated from 2002 onwards because the EES became incorporated with the comprehensive financial part of EU nations. From 2000-2010 by the Lisbon strategy there were witnessed some positive developments particularly the formation of a feminine work rate and pre-school childcare objectives. This gender development factually missing during the fiscal crisis in the first portion of the Europe 2020 policy and then reappeared in very weak form.

The EU policies related with social justice, financial and political empowerment of women. It also exhibits that the efforts of EU for gender equality based on policy, institutions and complex combination of gender legislation and strategy. All mentioned aspects reflect the improvement in social, political and economic sector in terms of equal status of women but despite of gender equality and mainstreaming strategies, many strategy zones of the EES still gender blind or ignorant of gender equality. Therefore gender mainstreaming has still artificial and is frequently overlooked by EU states both nation and organization level.

However it does not mean that EU does not act positively to achieve its fundamental aim of gender equality, it only clarify that apart of limited powers of EU, it acted remarkably

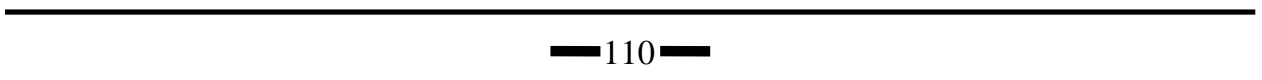




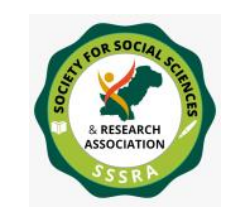

Pak. Journal of Int'L Affairs, Vol 4, Issue 2 (2021) Gender Parity and Women Empowerment ...

to provides equal rights to European women, but still target is not accomplished because of core bindings of states internal hard laws.

\section{CONCLUSION}

The socio-economic space among men and women in European society has reduced intensely in the $21^{\text {st }}$ century. However women in Europe still receive $16 \%$ less pay then men beside of the fact that equal remuneration was the keystone of the primary European treaty (the Treaty of Rome). Women also become important in European politics and there role is increasing day by day. The female representation is now reaching $31 \%$ in the European Parliament, and across Europe women now get $21 \%$ of representation in their respective parliaments. Yet, women are still less-represented in other parts of socioeconomic decision making.

Women have also made outstanding role in higher education. It was seemed very difficult in 1957 in many European countries where they reach today. The contributions of gender studies and activist movements of women should not be overlooked. Thanks to better statistics and more acute analysis, most equality actors are aware that there is still much to be done in Europe to achieve an environment where women want to live. The goals of physical veracity, being able to contribute and yield from eloquent work, and social and political are not attained for the major ration of Europe's women. The diversity of European realities is dramatic, ranging from Malta to Finland, Romania to the UK. It provides a corporeal laboratory for how values, policy and social action will be changing gender relations in the future. The most positive conclusion is that thanks to this learning laboratory, the experience of the European Union can help and provides hoards for other nations of the world that still have a long way to achieve the task of gender equality.

\section{RECOMONDATIONS}

The Sustainable Development Goals (SDGs), which is the part of 2030 agenda, proposed a factual chance to bring an enduring transformation for women's rights, equality and empowerment. For the sake of more improvement, it is commonly believe that European community should play more vital role in the subsequent zones such as identical pay scale for men and women because still women are payed in Europe 16\% less than men. They should also increase in political representation for women in every country's parliaments because it is also less than men. Women also need equal prospects, resources and responsibilities to recognise parity. At last the role of civil society organizations

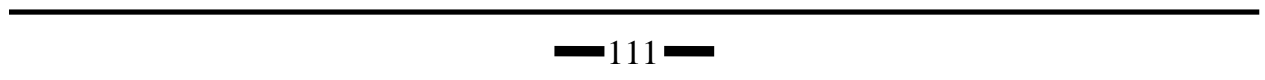


(CSO), including NGOs and free media and the private sector, which constitute the core edifice of the straight structure, should be more enunciated.

Lastly, women plays a very vital role in all walks of life because they belongs to the half portion of society and world cannot grows without provision of them. Gender equality and mainstreaming is improving in Europe but still it looks artificial and need grass root strength. There is a need of more hard legislation to resolve the issues of European women. In addition, the society made possible for women to proceed to high position in politics, business, and education. It is time for women to join equally in decision making in every walks of life, in social, political and economic sector as well as in the institutions of governance. 


\section{REFERENCES}

Debusscher, Petra (2015) “Gender Equality Policies in the European Union: Economic Integration and Feminist Transnational Advocacy," Belgium, University of Antwerp: About Gender, International Journal of Gender Studies, Vol 4: 1-19, https://doc.anet.be/docman/docman.phtml?file=.irua.ace739.129363.pdf (Accessed on May 24, 2018)

European Commission (2011) DG Employment, Social Affairs and Inclusion (As sighted: Debusscher, Petra (2015) "Gender Equality Policies in the European Union: Economic Integration and Feminist Transnational Advocacy," Belgium, University of Antwerp: About Gender, International Journal of Gender Studies, Vol 4: 1-19

https://doc.anet.be/docman/docman.phtml?file=.irua.ace739.129363.pdf (Accessed on May 24, 2018).

EU (1996) Incorporating Equal Opportunities for Women and Men into all Community Policies and Activities, COM (96) 67 final, http://eur-lex.europa.eu/legal content/EN/TXT/PDF/?uri=CELEX:51996DC0067\&from=EN(Accessed on May $28,2018)$.

Hoskyns, Catherine, (1996) Integrating Gender: women, law and politics in the European Union, Verso, London.

Kantola, Johanna (2010) Gender and the European Union, USA/UK: Palgrave Macmillan. Maastricht Treaty, February, 07, 1992, https://europa.eu/europeanunion/sites/europaeu/files/docs/body/treaty_on_europe an_union_en.pdf(Accessed on May 25, 2018)

Macrae, Heather (2010) “The EU as a Gender Equal Polity: Myths and Realities," Toronto: JCMS, Volume 48. Number1. pp. 155-174 
Moravcsik, A. (1993) "Preferences and power in the European Community: A liberal inter govern mentalist approach," Journal of Common Market Studies, 31, 473526.

Pinder, John and Usherwood, Simon ( $3^{\text {rd }}$ Ed 2013) The European Union: A Very Short Introduction, UK/ USA: Oxford University Press.

Rees, T. (1998) Mainstreaming Equality in the European Union. Education, Training and Labour Market Policies, London: Routledge.

Shaw, J. (2002) “The European Union and Gender Mainstreaming”, Feminist Legal Studies, Vol 3, no. 10, pp. 213-226.

Subramanian. S, (2004) Human Rights international challenge, Manas Publication, New Delhi.

Squires, Judith (2005), Is Mainstreaming Transformative? Theorizing Mainstreaming in the Context of Diversity and Deliberation, in «Social Politics: International Studies in Gender, State \& Society», vol. 12, no. 3, pp. 366-388.

Squires, Judith (2007) "Diversity Mainstreaming: Moving Beyond Technocratic and Additive Approaches," UK: Budrich Journals of Famina Politics, Vol. 12, No. 3, 45-56, https://budrichjournals.de/index.php/feminapolitica/article/download/1731/1364 (Accessed on May 26, 2018).

The Treaty of Rome, $25^{\text {th }}$, March, 1957, https://ec.europa.eu/romania/sites/romania/files/tratatul_de_la_roma.pdf (Accessed on May 24, 2018)

UN Fourth World Conference on Women (1995) http://www.un.org/womenwatch/daw/beijing/pdf/Beijing\%20full\%20report\%20E. pdf(Accessed on May 28, 2018). 
Van der Vleuten, A. (2007), The Price of Gender Equality: Member States and Governance in the European Union, Aldershot/ UK: Ashgate.

Verloo, M and Lombardo, E. (2007), "Contested Gender Equality and Policy Variety in Europe: Introducing a Critical Frame Analysis Approach", in M. Verloo (ed.) Multiple Meanings of Gender Equality. A Critical Frame Analysis of Gender Policies in Europe, Budapest: Central European University Press.

Woodward, A. (2012) "From Equal Treatment to Gender Mainstreaming and Diversity Management", in G. Abels, G. and J. Mushaben (eds. by), Gendering the European Union, Basingstoke, Hampshire, Palgrave Press, pp. 85-103. 